\begin{tabular}{|c|c|}
\hline $\begin{array}{l}\text { Published by LP4MK STKIP PGRI LUBUKLINGGAU } \\
\text { Prodi Pendidikan Bahasa Indonesia, STKIP PGRI Lubuklinggau, } \\
\text { South Sumatera, Indonesia }\end{array}$ & $\begin{array}{r}\text { Vol. 3, No. 2, } 2020 \\
\text { Page: } 310-324\end{array}$ \\
\hline
\end{tabular}

\title{
PENGEMBANGAN BUKU SUPLEMEN TEKS FABEL DALAM MENINGKATKAN PEMAHAMAN NILAI ANTIKORUPSI SISWA SMP KELAS VII
}

\author{
Andi Prastiyo*1, Setya Yuwana Sudikan ${ }^{2}$, Suyatno ${ }^{3}$ \\ ${ }^{1,2,3}$ Program Studi Magister Pendidikan Bahasa dan Sastra, Universitas Negeri Surabaya \\ JIn. Lidah Wetan, Lidah Weta, Kec. Lakarsantri, Kota Surabaya, Indonesia \\ Email: prastiyoand@gmail.com ${ }^{* 1}$
}

\begin{abstract}
Abstrak
Tujuan penelitian ini adalah untuk menghasilkan deskripsi tentang 1) proses pengembangan buku suplemen teks fabel untuk pemahaman nilai antikorupsi siswa SMP kelas VII, 2) kualitas pengembangan buku suplemen teks fabel untuk pemahaman nilai antikorupsi siswa SMP kelas VII yang diukur berdasarkan kevalidan dan kepraktisan buku suplemen. Penelitian ini dirancang menggunakan metode penelitian pengembangan. Prosedur pengembangan buku suplemen menggunakan model pengembangan 4-D. Proses pengembangan buku suplemen model ini terdiri atas empat tahap, yaitu pendefinisian, perancangan, pengembangan, dan penyebaran. Teknik pengumpulan data yang digunakan berupa studi pustaka dan observasi. Studi pustaka digunakan untuk memperoleh dasar-dasar dan pendapat secara tertulis sehingga didapatkan data sekunder yang akan digunakan sebagai landasan perbandingan antara teori dengan praktiknya di lapangan. Observasi digunakan untuk melihat keterlaksanaan proses pengembangan meliputi pendefinisian, perancangan, dan pengembangan. Hasil penelitian menunjukkan bahwa buku suplemen teks fabel layak digunakan karena dapat meningkatkan pemahaman nilai antikorupsi siswa. Hal ini dibuktikan dengan kualitas buku suplemen teks fabel sudah valid, praktis, dan efektif digunakan. Rincian kepraktisan, yaitu hasil keterlaksanaan rencana pelaksanaan pembelajaran sebesar $80,1 \%$ berkategori baik, hasil respons guru sebesar $81,3 \%$ berkategori baik, dan hasil respons siswa sebesar $85,7 \%$ berkategori sangat baik. Kemudian, tingkat keefektifan buku suplemen teks fabel berkategori sangat baik. Rincian keefektifan, yaitu hasil aktivitas guru sebesar $88,4 \%$ berkategori sangat baik, hasil aktivitas siswa sebesar $85,7 \%$ berkategori sangat baik, dan hasil ketuntasan belajar sebesar $99 \%$ berkategori sangat baik.
\end{abstract}

Kata kunci: pengembangan, buku suplemen, teks fabel, nilai antikorupsi

\section{THE DEVELOPMENT OF A FABLE TEXT SUPPLEMENT BOOK IN IMPROVING THE UNDERSTANDING OF THE ANTI-CORRUPTION VALUES OF THE VII GRADE JUNIOR HIGH SCHOOL STUDENTS}

\begin{abstract}
The purpose of this study was to produce a description of 1) the process of developing a fable text supplement book for understanding the anti-corruption values of seventh grade junior high school students, 2) the quality of fable text supplement book development for understanding the anti-corruption value of seventh grade junior high school students as measured by the validity and practicality of the supplement book. This study was designed using development research


methods. The supplement book development procedure uses a 4-D development model. The process of developing this supplement book model consists of four stages, namely definition, design, development, and distribution. The data collection techniques used were literature study and observation. Literature study is used to obtain written basics and opinions so that secondary data is obtained which will be used as a basis for comparison between theory and practice in the field. Observation is used to see the implementation of the development process including definition, design and development. The results showed that the fable text supplement book was appropriate because it could improve students' understanding of the anti-corruption values. This is evidenced by the quality of the fable text supplement book that is valid, practical, and effectively used. Details of practicality, namely the results of the implementation of the learning implementation plan of $80.1 \%$ in the good category, the results of the teacher's response to $81.3 \%$ in the good category, and the results of the student's response by $85.7 \%$ in the very good category. Then, the level of effectiveness of the fable text supplement book was categorized as very good. Details of the effectiveness, namely the results of teacher activity by $88.4 \%$ in the very good category, the results of student activity by $85.7 \%$ in the very good category, and the results of learning completeness by $99 \%$ in the very good category.

Keywords: development, supplement book, fable text, anti-corruption values

\section{A. Pendahuluan}

Paradigma pembelajaran bahasa Indonesia berbasis teks tentu memiliki tujuan yang baik guna mempertinggi derajat bahasa Indonesia dalam dunia pendidikan. Ada beberapa alasan yang dapat dikemukakan mengenai pembelajaran bahasa Indonesia berbasis teks. Pertama, melalui teks, kemampuan berpikir siswa dapat dikembangkan. Kedua, materi pembelajaran berupa teks lebih relevan dengan karakteristik kurikulum 2013 karena menetapkan pencapaian kompetensi siswa harus mencakup tiga ranah pendidikan, yaitu sikap, pengetahuan, dan keterampilan (Dewantara dkk., 2019; Satinem dkk., 2020).

Dalam kurikulum 2013 untuk pelajaran bahasa Indonesia membahas berbagai macam teks. Salah satu teks yang dibahas di kelas VII adalah teks fabel. Cerita fabel merupakan gambaran perilaku manusia yang diperankan oleh para binatang sebagai media pengingat yang sekaligus penghibur. Sebagaimana pendapat Zaidan dkk. (2007) dan Ernawati (2019)) bahwa fabel adalah cerita singkat yang berisi ajaran moral dengan tokoh binatang yang bersifat seperti manusia. Cerita fabel termasuk cerita rakyat kategori dongeng. Sebagai gambaran sebuah kebenaran yang memiliki fungsi menghibur pula, dongeng lebih menekankan pada isi yang mengandung pelajaran moral dan sindiran (Danandjaja, 2000; Khuzaemah \& Ummi, 2019). Hal ini menunjukkan kefiktifan sebuah dongeng yang penuh dengan ajaran yang dapat diambil. 
Dengan fabel, kita mampu menuntun kecerdasan emosi anak, mendidik, memberi hiburan, dan membentuk kepribadian anak. Hal ini sesuai dengan manfaat dari fabel sebagai karya sastra yaitu memiliki nilai dan manfaat bagi pembacanya (Noermanzah, 2017). Berdasarkan hal tersebutlah nilai antikorupsi mencoba untuk dikolaborasikan dengan teks fabel karena akan lebih dapat berterima di kala siswa telah jenuh dengan pemahaman nilai moral atau nasihatnasihat yang sifatnya mencemooh secara langsung. Menurut Syarbini \& Arbain (2014), nilai antikorupsi itu terdiri atas kejujuran, kepedulian, kemandirian, kedisiplinan, pertanggungjawaban, kerja keras, kesederhanaan, keberanian, dan keadilan. Nilai-nilai semacam ini sebenarnya telah banyak digunakan dalam tema fabel hanya saja belum ada pembahasan secara khusus dalam buku pembelajaran.

Upaya penanaman moral dan pemberantasan praktik korupsi yang bersifat preventif harus digalakkan khususnya dalam rangkaian cerita yang dikemas dalam fabel. Selama ini penanganan kasus korupsi baru pada tatanan represif. Budaya korupsi terbentuk karena adanya kebiasaan kurangnya menjunjung tinggi nilai moral. Kepentingan dan kebutuhan yang ingin dipenuhi secara singkat, menyebabkan ketidakpedulian terhadap hak orang lain. Oleh karena itu, pemberantasan korupsi tidak dapat dilakukan secara instan, namun harus berkelanjutan dan penyadaran secara laten, yaitu melalui dunia pendidikan. Menilik hal tersebut, pengembangan bahan ajar, utamanya buku suplemen memiliki ruang yang cukup guna memperluas materi-materi jenis teks salah satunya, yaitu teks fabel. Oleh karena itu, sampai saat ini banyak kalangan yang meneliti tentang pengembangan bahan ajar teks fabel. Seperti halnya yang dilakukan Sumartini \& Hapsari (2016), yaitu melakukan penelitian tentang pengembangan buku pengayaan apresiasi teks fabel bermuatan nilai-nilai karakter. Kemudian, Rahmawati dkk. (2016) yang mengembangkan media pembelajaran menulis teks fabel dengan Macromedia Flash. Begitu pula dengan Gharini \& Subyantoro (2018) yang mengembangkan media pembelajaran kartu bergambar sebagai penunjang kreativitas penyusunan teks fabel. Namun, 
berdasarkan penelitian relevan tersebut belum ada yang menyangkut pemahaman nilai antikorupsi. Selain itu, proses atau prosedur pengembangannya juga belum dijelaskan secera terperinci. Padahal, dalam proses pengembangan produk memerlukan sistematika atau prosedur dan data walaupun data sekunder, guna menghasilkan produk yang dapat dikategorikan layak. Inilah yang membedakan dengan penelitian pengembangan buku suplemen teks fabel untuk pemahaman nilai antikorupsi siswa SMP kelas VII.

Menurut Prastowo (2013), bahan ajar harus disusun secara sistematis baik itu bahan yang berupa informasi, alat, dan teks. Di dalamnya memuat secara utuh kompetensi yang akan diajarkan pada siswa yang akan menentukan keberhasilan dalam kegiatan belajar mengajar untuk mencapai tujuan (Noermanzah \& Friantary, 2019). Berdasarkan beberapa hal tersebut, maka diperlukan pengembangan buku suplemen teks fabel untuk pemahaman nilai antikorupsi siswa SMP dengan beberapa alasan. Pertama, belum ada buku suplemen teks fabel yang bermuatan nilai antikorupsi. Kedua, dalam kurikulum 2013 pemerintah tidak hanya berupaya memperbaiki kualitas kurikulum, tetapi juga memperbaiki fasilitas dalam pengimplementasian kurikulum tersebut. Salah satunya dengan diterbitkannya buku siswa dan buku pedoman guru. Buku tersebut, baik pengembangan serta pendalaman isi materi perlu ditunjang dengan buku suplemen yang meterinya disesuaikan dengan kebutuhan peserta didik dengan lingkungan dan masalah di sekitar. Sebagaimana yang dijelaskan oleh Kemendikbud (2018) dan Suryani \& Rasdawita (2019) bahwa kontekstualisasi pembelajaran dilakukan dengan mengaitkan materi-materi yang dipelajari dengan situasi dan kondisi di lingkungan setempat. Tokoh binatang dalam cerita fabel lebih mudah dijumpai dalam kehidupan sehari-hari karena letak sekolah penelitian berada di pedesaan. Penelitian pengembangan buku suplemen teks fabel untuk pemahaman nilai antikorupsi ini dilakukan di SMP Negeri 2 Sugio, Lamongan, Jawa Timur.

Berdasarkan beberapa hal tersebut, maka rumusan masalah penelitian ini, yaitu "Bagaimanakah proses pengembangan dan kualitas buku suplemen teks fabel untuk pemahaman nilai antikorupsi siswa SMP kelas VII?" Penelitian ini 
bertujuan untuk menghasilkan deskripsi proses dan kualitas pengembangan buku suplemen teks fabel untuk pemahaman nilai antikorupsi siswa SMP kelas VII. Secara teoretis, penelitian ini diharapkan dapat memberikan sumbangan pemikiran dalam pembelajaran dan secara praktisnya dapat memberikan manfaat bagi siswa, guru, serta sekolah dalam upaya pemahaman nilai korupsi sehingga dapat sebagai alat secara preventif untuk mencegah tindak korupsi.

\section{B. Metode Penelitian}

Metode penelitian yang digunakan yaitu metode penelitian pengembangan (Research and Development/R\&D), yang bertujuan menghasilkan produk berupa buku suplemen teks fabel. Dalam mengembangkan produk tersebut, dilakukan validasi. Oleh karena itu resarch and development dijadikan metode penelitian ini. Hal ini sesuai yang disampaikan oleh Borg and Gall (dalam Sugiyono, 2012) bahwa metode penelitian dan pengembangan merupakan metode penelitian yang digunakan untuk mengembangkan atau memvalidasi produk-produk yang digunakan dalam pendidikan dan pembelajaran. Kemudian, menurut Putra (2015) Research and Development (R\&D) merupakan metode penelitian secara sengaja, sistematis, untuk menemukan, memperbaiki, mengembangkan, menghasilkan, maupun menguji keefektifan produk, model, maupun metode/ strategi/ cara yang lebih unggul, baru, efektif, efisien, produktif, dan bermakna. Oleh karena itu, metode ini pada dasarnya merupakan metode untuk menghasilkan produk secara sistematis yang dapat dipertanggungjawabkan karena telah melalui pengujian.

Penelitian pengembangan buku suplemen teks fabel untuk pemahaman nilai antikorupsi siswa SMP kelas VII ini menggunakan model pengembangan Thiagarajan dkk. (1974) yang dikenal dengan model 4-D (define, design, develop, dan disseminate), yaitu pendefinisian, perancangan, pengembangan, dan penyebaran. Pada penelitian pengembangan ini tahap penyebaran tidak dilakukan karena keterbatasan waktu peneliti. Rancangan penelitian ini dipilih karena (1) searah dengan penelitian ini, yakni mengembangkan buku suplemen teks fabel untuk pemahaman nilai antikorupsi siswa SMP kelas VII, (2) uraian dan 
penjelasan pada penelitian pengembangan model 4-D lebih lengkap dan sistematis, (3) dalam pengembangannya keterlibatan ahli diperlukan sehingga sebelum dilakukan uji coba di lapangan buku suplemen telah dilakukan revisi berdasarkan penlilaian, saran, dan masukan para ahli, dan (4) buku suplemen merupakan alat bantu untuk proses pembelajaran sehingga model 4-D dipilih dalam pengembangan.

Teknik pengumpulan data penelitian ini meliputi dua hal. Pertama, teknik pengumpulan data proses pengembangan buku suplemen, yaitu digunakan teknik studi pustaka dan observasi. Teknik observasi digunakan untuk melihat keterlaksanaan proses pengembangan meliputi pendefinisian, perancangan, dan pengembangan buku suplemen. Kedua, teknik pengumpulan data kualitas pengembangan buku suplemen, yaitu angket, observasi, dan tes. Teknik angket digunakan untuk memperoleh data yang berupa angka atau nilai kevalidan buku suplemen dan data kepraktisan respons guru serta respons siswa setelah produk digunakan. Instrumen yang digunakan, yaitu lembar angket validasi, respons guru dan siswa. Teknik observasi digunakan untuk memperoleh data kepraktisan keterelaksanaan Rencana Pelaksanaan Pembelajaran (RPP) dan data keefektifan, yang meliputi aktivitas siswa dan aktivitas guru yang terjadi selama proses pembelajaran. Instrumen yang digunakan, yaitu lembar observasi keterlaksanaan RPP, aktivitas guru dan siswa. Teknik tes digunakan untuk memperoleh data hasil belajar siswa setelah menggunakan produk, yaitu berupa soal.

Teknik analisis data pada penelitian ini, meliputi dua hal. Pertama, penganalisisan data yang digunakan dalam proses pengembangan buku suplemen dilakukan dengan teknik deskriptif kualitatif. Teknik ini digunakan untuk mengolah data kualitatif yang berupa saran, tanggapan, komentar, dan masukan validator serta guru. Kedua, penganalisisan data kualitas pengembangan buku suplemen, yaitu uji validitas dan uji reabilitas. Teknik digunakan untuk mengolah data angka yang diperoleh dari lembar observasi, angket, dan tes. Dalam penelitian ini, nilai kelayakan ditentukan jika hasil kevalidan, kepraktisan, dan kefektifan minimal mencapai nilai C (cukup). 


\section{Hasil Penelitian dan Pembahasan}

\section{Hasil Penelitian}

Hasil penelitian kualitas buku suplemen berupa data-data statistik deskriptif. Adapun data tersebut diperoleh dari hasil pengukuran validasi oleh validator, tingkat kepraktisan, dan tingkat kefektifan. Hasil tersebut berupa angka dalam bentuk persentase. Kevalidan buku suplemen pada penelitian ini berdasarkan dari validator kelayakan isi dengan persentase $82,8 \%$ kategori baik, dari validator kelayakan bahasa dengan persentase $84,4 \%$ kategori baik, dari validator kelayakan penyajian dengan persentase $83,3 \%$ kategori baik, dan dari validator kelayakan kegrafikaan dengan persentase 96,4\% kategori sangat baik. Berdasarkan hasil rekapitulasi validasi buku suplemen diperoleh hasil rerata persentase kevalidan buku suplemen sebesar $86,7 \%$ dengan kategori sangat baik.

Untuk kepraktisan buku suplemen yang dikembangkan, diukur dari keterlaksanaan RPP, respons guru dan respons siswa. Keterlaksanaan RPP merupakan kemampuan guru dalam mengelola kegiatan belajar mengajar yang meliputi kegiatan pendahuluan, kegiatan inti, dan kegiatan penutup. Untuk memperolah data keterlaksanaan RPP dilakukan pengamatan sebanyak enam kali pertemuan kegiatan pembelajaran. Pada pertemuan pertama diperoleh persentase $73 \%$ kategori cukup baik. Pertemuan kedua diperoleh persentase $81 \%$ kategori baik. Pertemuan ketiga diperoleh persentasi $80 \%$ kategori baik. Pertemuan keempat sampai dengan pertemuan keenam diperoleh persentase $81 \%$ kategori baik. Berdasarkan data tersebut maka diperoleh rerata persentase tingkat keterlaksanaan RPP sebesar 80,1\% kategori baik.

Respon guru diperolah dari angket yang telah diisi oleh dua guru yang di dalamnya terdapat delapan indikator sebagai penilaian terhadap pengembangan buku suplemen, yaitu: 1) kemudahan dalam memahami materi memperoleh hasil sebesar $90 \%$ dengan kategori baik; 2) kemudahan dalam menjelaskan meteri memperoleh hasil sebesar $80 \%$ dengan kategori baik; 3) kemudahan dalam memberi contoh memperolah hasil $80 \%$ dengan kategori baik; 4) kemudahan dalam mengoordinasi peserta didik diperoleh hasil $80 \%$ dengan kategori cukup 
baik; 5) kemudahan dalam menerapkan tes memperolah hasi $80 \%$ dengan kategori baik; 6) kemudahan dalam menerapkan buku suplemen memperoleh hasil $80 \%$ dengan kategori baik; 7) kemudahan dalam mencari materi memperoleh hasil $80 \%$ dengan kategori baik; dan 8) kemudahan dalam memahami contoh bacaan memperoleh hasil sebesar $80 \%$ dengan kategori baik. Secara keseluruhan, respons guru terhadap buku suplemen mendapat persentase $81,3 \%$ dengan kategori baik.

Data berikutnya yang digunakan untuk mengukur kepraktisan buku suplemen berupa hasil respons siswa. Sebagaimana respons guru, dalam angket respons siswa juga terdapat beberapa indikator, yaitu: 1) pemilihan bacaan dalam buku suplemen yang digunakan memperoleh hasil $85 \%$ dengan kategori sangat baik; 2) penyajian materi dalam buku suplemen yang digunakan memperoleh hasil $80 \%$ dengan kategori baik; 3) penggunaan kalimat pelatihan dalam buku suplemen yang digunakan memperoleh hasil $77,5 \%$ dengan kategori baik; 4) motivasi dalam penggunaan buku suplemen memperoleh hasil 91,3\% dengan kategori sangat baik; 5) keberadaan buku suplemen membantu peserta didik untuk belajar memperoleh hasil $86,9 \%$ dengan kategori sangat baik; 6) pemilihan soal-soal latihan dalam buku suplemen yang digunakan memperoleh hasil $80 \%$ dengan kategori baik; 7) penggunaan buku suplemen dapat melatih peserta didik untuk bersikap sesuai nilai antikorupsi memperolah hasil $86,3 \%$ dengan kategori sangat baik; dan 8) teks dalam buku suplemen yang digunakan mengandung nilai antikorupsi memperoleh hasil $95 \%$ dengan kategori sangat baik. Hasil respons peserta didik secara keseluruhan persentase yang diperoleh sebesar $85,2 \%$ dengan kategori sangat baik.

Tingkat keefektifan pengembangan buku suplemen diperolah dari pengamatan aktivitas guru, aktivitas siswa, dan ketuntasan belajar. Data pengamatan aktivitas guru diperoleh dari lembar pengamatan yang di dalamnya berisi aspek-aspek yang digunakan untuk menilai aktivitas guru dalam kegiatan pembelajaran. Pengamatan ini dilakukan sebanyak enam kali pertemuan pembelajaran, yaitu: 1) pertemuan I aktivitas guru memperoleh $88,2 \%$ dengan kategori sangat baik; 2) pertemuan II aktivitas guru memperoleh $89,4 \%$ dengan 
kategori sangat baik; 3) pertemuan III aktivitas guru memperoleh $85,9 \%$ dengan kategori sangat baik; 4) pertemuan IV aktivitas guru memperoleh $88,2 \%$ dengan kategori sangat baik; dan 5) pertemuan $\mathrm{V}$ dan $\mathrm{VI}$ jumlah aktivitas guru memperoleh $89,4 \%$ dengan kategori sangat baik. Berdasarkan data tersebut dapat dikatakan bahwa aktivitas guru mengalami kenaikan fluktuatif. Namun, tidak memengaruhi keberhasilan guru dalam pembelajaran karena rerata persentasenya $88,4 \%$ kategori sangat baik.

Data aktivitas siswa juga diperoleh dari pengamatan terhadap 32 siswa selama enam kali pertemuan pembelajaran, yaitu: 1) pertemuan I aktivitas siswa memperoleh $82,9 \%$ dengan kategori baik; 2) pertemuan II aktivitas siswa memperoleh $88,6 \%$ dengan kategori sangat baik; 3) pertemuan III aktivitas siswa memperoleh $82,9 \%$ dengan kategori baik; 4) pertemuan IV aktivitas siswa memperoleh $85,7 \%$ dengan kategori sangat baik; 5) pertemuan $\mathrm{V}$ aktivitas siswa memperoleh $88,6 \%$ dengan kategori sangat baik; dan 6) pertemuan VI aktivitas siswa memperoleh $85,7 \%$ dengan kategori sangat baik. Aktivitas guru sebagaimana aktivitas siswa juga mengalami kenaikan fluktuatif. Namun, tetap dikatakan berhasil karena rerata persentasi yang memperoleh $85,7 \%$ dengan kategori sangat baik.

Tolak ukur keefektifan pengembangan buku suplemen yang terakhir adalah melihat hasil ketuntasan belajar siswa. Penilaian disusun berdasarkan tuntutan indikator yang terdapat dalam setiap Kompetensi Dasar (KD). Perserta didik dikatakan tuntas apabila berhasil menuntaskan setiap kompetensi, yaitu: 1) ketuntasan belajar kompetensi sikap (sosial dan spiritual); 2) ketuntasan belajar kompetensi pengetahuan; dan 3) ketuntasan belajar kompetensi keterampilan. Ketuntasan minimal aspek sikap adalah B sedangkan ketuntasan minimal untuk kompetensi pengetahuan dan keterampilan yaitu 75. Pencapaian ketuntasan secara klasikal $\geq 75 \%$ yang mencakup hasil penilaian kompetensi sikap (sosial dan spirirtual), pengetahuan, dan keterampilan. Dalam penelitian ini, hasil ketuntasan kompetensi peserta didik aspek sikap memperolah nilai rata-rata dengan kategori baik dan ketuntasan klasikal sebesar 100\%. Hasil ketuntasan kompetensi peserta 
didik aspek pengetahuan memperoleh nilai rata-rata 85,5 dan ketuntasan klasikal sebesar $97,5 \%$. Hasil ketuntasan kompetensi peserta didik aspek keterampilan mencapai nilai rata-rata 85,8 dan ketuntasan klasikal sebesar $100 \%$. Hasil persentase ketuntasan klasikal masing-masing aspek menunjukkan bahwa buku suplemen teks fabel untuk pemahaman nilai antikorupsi kelas VII efektif dalam mencapai kreteria ketuntasan belajar siswa.

\section{Pembahasan}

Buku suplemen teks fabel layak digunakan karena dapat meningkatkan pemahaman nilai antikorupsi siswa. Hal ini menunjukkan fabel yang disusun mengandung nilai pendidikan karakter antikorupsi sesuai harapan dari tujuan penulisan karya sastra yaitu harus mengandung nilai dan manfaat kepada pembacanya (Irma, 2018; Noermanzah, 2017). Layaknya buku suplemen teks fabel ini dibuktikan juga dengan kualitas buku suplemen teks fabel sudah valid, praktis, dan efektif digunakan. Rincian kepraktisan, yaitu hasil keterlaksanaan rencana pelaksanaan pembelajaran sebesar $80,1 \%$ berkategori baik, hasil respons guru sebesar $81,3 \%$ berkategori baik, dan hasil respons siswa sebesar $85,7 \%$ berkategori sangat baik. Kemudian, tingkat keefektifan buku suplemen teks fabel berkategori sangat baik. Rincian keefektifan, yaitu hasil aktivitas guru sebesar $88,4 \%$ berkategori sangat baik, hasil aktivitas siswa sebesar $85,7 \%$ berkategori sangat baik, dan hasil ketuntasan belajar sebesar $99 \%$ berkategori sangat baik.

Penelitian ini berhasil juga didukung dengan penggunaan model pengembangan Thiagarajan dkk. (1974) sebagaimana yang telah dijelaskan dalam metode penelitian. Model pengembangan ini diawali dengan tahap pendifinisian yang terdiri atas analisis awal akhir, analisis siswa, analisis konsep, analisis tugas, dan analisis tujuan pembelajaran. Pada tahap analisis awal akhir diperoleh informasi tentang pengetahuan, keterampilan, dan sikap siswa yang digunakan untuk mencapai tujuan pembelajaran. Informasi tersebut terkait dengan kefektifan KI dan KD yang digunakan, sebagai tujuan pembelajaran, dan kesesuaian indikator. Selain mengkaji kurikulum, diperlukan juga informasi tentang 
kesulitan-kesulitan yang dialami guru yang berkenaan dengan buku pelajaran yang ada. Untuk mendapatkan informasi tersebut dilakukan wawancara dan diskusi terhadap guru sebagai staf pengajar bahasa Indonesia. Berdasarkan hasil wawancara dan diskusi dengan guru, maka guru sepakat jika ada buku suplemen yang dapat digunakan untuk mempermudah siswa dalam memahami materi pembelajaran, khususnya teks fabel.

Pada tahap analisis siswa diperoleh informasi tentang karekeristik siswa, yaitu: 1) tingkat kemampuan peserta didik SMP Negeri 2 Sugio bervariasi; 2) proses pembelajaran berprinsip pada kegiatan mendapatkan pengetahuan dahulu, lalu keterampilan; 3) pengetahuan bersifat sesaat dan minim keterampilan; 4) pembelajaran sebagian bersifat monoton; dan 5) peserta didik mampu berbahasa lebih baik dan benar dalam bahasa tulis dibanding lisan. Peserta didik mampu membaca format informasi yang disajikan dalam berbagai bentuk (tulis dan gambar). Peserta didik terbiasa menggunakan teknologi informasi. Peserta didik lebih berminat pada materi yang berupa praktik dibanding teori.

Pada tahap analisis konsep, materi-materi kemudian dikonsep, disusun, dan diajarkan pada peserta didik melalui pengembangan buku suplemen dengan muatan pemahaman nilai antikorupsi. Buku suplemen tersebut disajikan dengan tema yang disesuaikan dengan materi-materi yang diajarkan. Penyajian buku suplemen ini meliputi aspek pengetahuan, keterampilan dan sikap.

Tahap selanjutnya adalah analisis tugas yang merupakan kumpulan prosedur untuk menentukan struktur isi buku suplemen yang akan dikembangkan. Dalam pembelajaran teks fabel ada dua KD, yaitu pengetahuan dan keterampilan. Untuk mencapai kompetensi tersebut dirumuskan tugas-tugas yang harus dilakukan siswa sebagai berikut: a) menyimpulkan ciri-ciri teks fabel; b) mengidentifikasi jenis-jenis teks fabel; c) mendaftar kata dan kalimat teks fabel; d) menentukan unsur dalam menceritakan kembali isi teks fabel; e) menulis kembali isi teks fabel berdasarkan urutan peristiwa; f) menceritakan kembali teks fabel; g) mengidentifikasi struktur teks fabel; h) memvariasikan pengungkapan 
struktur teks fabel; i) menyimpulkan prinsip penggunaan kata dan kalimat dalam teks fabel; j) merancang tokoh, penokohan, dialog, dan latar sesuai teks fabel; k) merancang pemeranan teks fabel; dan I) memerankan teks fabel. Adapun aktivitas yang harus dilakukan peserta didik dalam melaksanakan tugas tersebut, yaitu menanya, mengumpulkan informasi, mengasosiasi, dan mengomunikasikan. Tahap analisis tujuan pembelajaran berisi informasi tentang tujuan pembelajaran pada buku suplemen yang dikembangkan berupa kompetensi sikap, kompetensi pengetahuan, dan komptensi keterampilan.

Tahap yang kedua dalam model Thiagarajan dkk. (1974), yaitu perancangan yang terdiri atas perancangan tes, pemilihan media, penyusunan format, dan desain awal. Perancangan tes berisi penentuan jenis tes, soal latihan, dan skor pada setiap butir soal. Pemilihan media berisi penentuan gambar yang disesuaikan dengan materi. Penyusunan format berisi penentuan komposisi halaman, jenis huruf, warna huruf, jenis kertas, dan aktivitas siswa. Desain awal berisi pembuatan desain halaman sampul, menyusun konten, dan melakukan telaah.

Tahap ketiga, yaitu pengembangan yang terdiri dari validasi draf I, uji coba terbatas, dan uji coba luas. Pertama, validasi draf I berisi tanggapan validator ahli (kelayakan isi, kelayakan bahasa, kelayakan penyajian, dan kegrafikaan) dan teman sejawat mengenai buku suplemen yang dikembangkan. Untuk hasil kevalidan secara persentase dari validator memperoleh $86,7 \%$ kategori sangat baik telah diuraikan pada sub hasil penilitian. Selanjutnya, dilakukan revisi dan menghasilkan buku suplemen draf II. Kedua, uji coba terbatas berisi penggunaan buku suplemen pemahaman nilai antikorupsi dra II dalam pertemuan pembelajaran terhadap sepuluh siswa. Pada uji coba terbatas ini ditemukan beberapa permasalahan, yaitu alokasi waktu kurang mencukupi dan kurangnya contoh jawaban sehingga siswa kesulitan dalam menyelesaikan latihan. Dari permasalahan yang muncul tersebut kemudian dilakukan revisi sehingga menghasilkan buku suplemen pemahaman nilai antikorupsi draf III. Ketiga, uji coba luas, yaitu dengan melibatkan 32 siswa dalam enam kali pertemuan pembelajaran. Dalam uji coba luas ini rencana pelaksanaan pembelajaran 
dipersiapkan dengan enam materi pertemuan. Alokasi waktu yang diperlukan, yaitu $2 \times 40$ menit untuk sekali pertemuan. Untuk pelaksanaan uji coba luas, peneliti membuat instrumen lembar pengamatan keterlaksanaan RPP yang hasilnya sebesar $80,1 \%$ kategori baik. Pada saat guru melakukan uji coba didapatkan pula hasil dari aktivitas guru selama mengelola pembelajaran dengan menggunakan buku suplemen sebesar $88,4 \%$ kategori baik. Selain itu, memuat pula gambaran aktivitas siswa selama proses pembelajaran dengan menggunakan buku suplemen yang dikembangkan sebesar $85,7 \%$ kategori sangat baik. Uji coba luas ini juga digunakan untuk mengetahui respons guru yang hasilnya sebesar $81,3 \%$ kategori baik dan respons siswa terhadap buku suplemen yang dikembangkan yang hasilnya sebesar $85,2 \%$ kategori sangat baik. Selain pemerolehan data dalam bentuk angka dalam uji coba luas ini juga diperoleh tanggapan dari osbserver dan responder. Tanggapan ini diperoleh dari kolom komentar/saran lembar instrumen/angket keterlaksaanaan RPP, aktivitas guru, aktivitas siswa, respons guru, dan respons siswa. Berdasarkan tanggapantanggapan tersebut kemudian dilakukan tindak lanjut atau perbaikan terhadap pengembangan buku suplemen teks fabel sehingga dihasilkan draf IV sebagai produk final.

\section{Simpulan}

Berdasarkan uraian hasil penelitian dan pembahasan tersebut maka dapat disimpulkan bahwa buku suplemen teks fabel untuk pemahaman nilai antikorupsi siswa SMP kelas VII secara kualitas dapat dinyatakan valid, praktis, dan efektif digunakan sebagai salah satu bahan ajar untuk pembelajaran di kelas. Kevalidan penelitian ini didasarkan hasil validasi kelayakan isi, bahasa, penyajian, dan kegrafikaan. Kepratisan didasarkan hasil keterlaksanaan RPP, respons guru, dan respons siswa. Keefektifan didasarkan hasil aktivitas guru dan siswa serta ketuntasan belajar. Kevalidan, kepraktisan, dan kefektifan buku suplemen tersebut tidak lepas dari proses pengembangannya yang melalui tiga tahapan. Pertama, yaitu tahap pendefinisian yang terdiri dari analisis awal akhir, analisis siswa, 
analisis konsep, analisis tugas, dan analisis tujuan pembelajaran. Kedua, yaitu tahap perancangan yang terdiri dari perancangan tes, pemilihan media, penyusunan format, dan desain awal. Ketiga, yaitu tahap pengembangan yang terdiri atas validasi draf I, uji coba terbatas, dan uji coba luas.

\section{Daftar Pustaka}

Danandjaja, J. (2000). Folklor Indonesia IImu Gosip dan Dongeng. Jakarta: Grafiti Press.

Dewantara, A. A. N. B. J., Sutama, I. M., \& Wisudariani, N. M. R. (2019). Pembelajaran Bahasa Indonesia Berbasis Teks di SMA Negeri 1 Singaraja. Jurnal Pendidikan Bahasa dan Sastra Indonesia Undiksha, 9(2). doi:10.23887/jjpbs.v9i2.20462

Ernawati, Y. (2019). Pengembangan Lembar Kerja Peserta Didik (LKPD) pada Materi Teks Fabel Berbasis Saintifik untuk Siswa SMP Kelas VIII. Diksa: Pendidikan Bahasa dan Sastra Indonesia, 5(2), 94-103. doi:10.33369/diksa.v5i2.9982

Gharini, R., \& Subyantoro, S. (2018). Pengembangan Media Pembelajaran Kartu Bergambar sebagai Penunjang Kreativitas Penyusunan Teks Fabel bagi Peserta Didik SMP Kelas VII. Jurnal Pendidikan Bahasa dan Sastra Indonesia,7(2),https://journal.unnes.ac.id/sju/index.php/jpbsi/article/view/2 4715

Irma, C. N. (2018). Nilai-Nilai Pendidikan Karakter dalam Novel Ibuk Karya Iwan Setyawan. RETORIKA: Jurnal Bahasa, Sastra, dan Pengajarannya, 11(1), 14. doi:10.26858/retorika.v11i1.4888

Kemendikbud. (2018). Materi Penyegaran Instruktur Kurikulum 2013 Sekolah Menengah Pertama Mata Pelajaran Bahasa Indonesia. Jakarta: Kemdikbud.

Khuzaemah, E., \& Ummi, H. U. (2019). Pengembangan Bahan Ajar Teks Fabel dan Cerpen Berorientasi Soft Skill. Indonesian Language Education and Literature, 4(2), 257. doi:10.24235/ileal.v4i2.4214

Noermanzah \& Friantary, H. (2019). Development of Competency-Based Poetry Learning Materials for Class X High Schools. International Journal of Recent Technology and Engineering, 8(4), 6631. 
Noermanzah, N. (2017). Plot in a Collection of Short Stories "Sakinah Bersamamu" Works of Asma Nadia with Feminimism Analysis. Humanus, 16(1), 30. doi:10.24036/jh.v16i1.7015

Prastowo, A. (2013). Pengembangan Bahan Ajar Tematik. Yogyakarta: Diva Press.

Putra, N. (2015). Research \& Development Penelitian dan Pengembangan. Depok: PT Raja Grafindo Persada.

Rahmawati, I. S., Roekhan, R., \& Nurchasanah, N. (2016). Pengembangan Media Pembelajaran Menulis Teks Fabel dengan Macromedia Flash bagi Siswa Smp. Jurnal Pendidikan: Teori, Penelitian, dan Pengembangan, 1(7), http://journal.um.ac.id/index.php/jptpp/article/view/6561

Satinem, S., Juwati, J., \& Noermanzah, N. (2020). Developing Teaching Material of Poetry Appreciation Based on Students Competency Analysis. English Review: Journal of English Education, 8(2), 237. doi:10.25134/erjee.v8i2.2707

Sugiyono. (2012). Metode Penelitian Kuantitatif, Kualitatif dan R\&D. Bandung: CV Alfabeta.

Sumartini, S. \& Hapsari, N. R. (2016). Pengembangan Buku Pengayaan Apresiasi Teks Fabel Bermuatan Nilai-Nilai Karakter bagi Siswa SMP. Jurnal Pendidikan Bahasa dan Sastra Indonesia, 5(2), https://journal.unnes.ac.id/sju/index.php/jpbsi/article/view/14697

Suryani, I., \& Rasdawita, R. (2019). Pengembangan Bahan Ajar Menulis Naskah Drama Berbasis Pendekatan Kontekstual di FKIP Universitas Jambi. Pena: Jurnal Pendidikan Bahasa dan Sastra, 8(1), 80-92. doi:10.22437/pena.v8i1.6565

Syarbini, A., \& Arbain, M. (2014). Pendidikan Anti Korupsi (Konsep, Strategi, dan Implementasi Pendidikan Anti Korupsi di Sekolah/Madrasah). Bandung: CV Alfabeta.

Thiagarajan, S; Semmel, D.S; \& Semmel, M.I. (1974). Instructional Development for Training Teachers of Exceptional Children: A Sourcebook. Indiana: Indiana University.

Zaidan, A. R., Rustapa, A. K., \& Hani'ah. (2007). Kamus Istilah Sastra. Jakarta: Balai Pustaka. 